\title{
Effect of Peripartum Organic Zinc and Copper Supplementation on Blood Metabolic and Hormonal Profiling of Primiparous Buffaloes
}

\author{
Arashdeep Kaur ${ }^{1 *}$, Prahlad Singh ${ }^{1}$, Mrigank Honparkhe ${ }^{1}$, R. S. Grewal ${ }^{2}$, \\ Ajeet Kumar ${ }^{1}$, Ashwani Kumar Singh ${ }^{1}$, Navdeep Singh ${ }^{3}$, \\ Shahbaz Singh Dhindsa ${ }^{1}$ and Ankit Kumar Ahuja ${ }^{1}$ \\ ${ }^{1}$ Department of Veterinary Gynaecology and Obstetrics, Guru Angad Dev Veterinary and \\ Animal Sciences University, Ludhiana, Punjab, India \\ ${ }^{2}$ Department of Animal Nutrition, Guru Angad Dev Veterinary and Animal Sciences \\ University, Ludhiana, Punjab, India \\ ${ }^{3}$ Directorate Livestock Farms, Guru Angad Dev Veterinary and Animal Sciences University, \\ Ludhiana, Punjab, India \\ *Corresponding author
}

\section{A B S T R A C T}

This study evaluated effects of organic trace mineral supplementation on hormonal and metabolic profile of primiparous buffaloes. Fourteen animals were randomly divided into two groups control (n=7) and treatment (n=7; Copper@225mg, Zinc@1.0gm per animal

\begin{tabular}{|l|}
\hline Key w or d s \\
Trace Minerals, \\
Buffalo, Metabolic \\
profile, Hormonal \\
Levels
\end{tabular}
per day). Treatment group was supplemented with organic copper at the rate of $225 \mathrm{mg}$ and Zinc at rate $1.0 \mathrm{gm}$ per animal per day respectively, in addition to normal feeding, 60 days before the expected date of calving till the date of artificial insemination. A significant $(\mathrm{p}<0.05)$ decrease in the serumnon-esterified fatty acid (NEFA) levels $(\mu \mathrm{mol} / \mathrm{l})$ was observed in supplemented $(388.88 \pm 3.73$ to $334.40 \pm 2.86 \mu \mathrm{mol} / \mathrm{l})$ than control group $(405.27 \pm 2.63$ to $352.92 \pm 5.45 \mu \mathrm{mol} / \mathrm{l})$ buffaloes. There was significant difference $(\mathrm{p}<0.05)$ in total protein $(\mathrm{g} / \mathrm{dl})$ values between treatment $(6.90 \pm 0.06$ to $7.35 \pm 0.05 \mathrm{~g} / \mathrm{dl})$ and control group $(6.22 \pm 0.20$ to $6.35 \pm 0.22 \mathrm{~g} / \mathrm{dl})$. Total protein $(\mathrm{g} / \mathrm{dl})$ increased after parturition in treatment group, while in control group the concentration of total protein did not change significantly after parturition. No significant difference was observed in progesterone $(0.33 \pm 0.01$ to $1.83 \pm 0.06 \mathrm{ng} / \mathrm{ml}$ vs. $0.26 \pm 0.01$ to $1.29 \pm 0.08 \mathrm{ng} / \mathrm{ml})$ and estradiol $(22.67 \pm 0.42$ to $140.82 \pm 0.51 \mathrm{pg} / \mathrm{ml}$ vs. $21.04 \pm 0.16$ to $145.23 \pm 0.39 \mathrm{pg} / \mathrm{ml})$ concentration in supplemented and control group, respectively. We concluded that supplementation of organic trace mineral significantly improved the total protein and nonesterified fatty acid levels in blood thus helps in proper mobilisation and utilisation of body reserves but it did not affect the blood hormonal profile significantly.

\section{Introduction}

World buffalo population is approximately 170 million with 97 percent in Asia (FAO
2004). India is possessing 56 percent of world buffalo population. The production potential of buffaloes is constrained by its low reproductive efficiency due to higher age of 
puberty, poor conception rates, longer service period and calving interval. The success of the dairy buffalo economy lies in optimal reproductive cycle of each individual buffalo in the herd within normal physiological range (Dhaliwal 2005). Any deviation in the breeding cycle results in a progressive economic loss due to prolonged dry period and reduced calvings and lactations during the life span of the animal (Singh et al., 2006).Minerals have basic key role in maintenance of metabolism and studies on their nutritional requirements in the body led to the classification of these minerals as macro and micro minerals. Adequate mineral intake and absorption is required for a variety of metabolic functions including immune response to pathogenic challenge, reproduction and growth (Garg et al., 2009).

Copper is mainly stored in the liver and is an enzyme component of essential metabolic processes. As an enzyme activator, it provides strong bones and joints and is heavily involved in the utilization of iron and thus the synthesis of hemoglobin. Through the promotion of superoxide dismutase, which deactivates free oxygen radicals, copper is also involved in cell protection and healthy immune system. Copper as a component of enzymes like peptidylglycine $\alpha$-amidating monoxygenase (PAM) and dopamine $\beta$ monoxygenase plays an important role in the activation of gonadotropin releasing enzyme (Michaluk and Kochman 2007). Cu appeared to be the cause of delayed puberty (possibly due to depressed basal LH release, affecting follicular estradiol production), reduced conception rate, and failure to ovulate (Phillippo et al., 1987). Copper interact with granulosa cells for production of estrogen. Altered plasmatic level of $\mathrm{Cu}$ confers changes in pattern and level of steroidal hormone synthesis leading to decline in overall fertility and altered reproductive behaviour in females eg. nymphomania in ewe (Hidiroglou 1979).
Zinc is the second most common trace element. It acts as an activator and a component of more than 300 enzymes and hormones. Zinc plays an important role in metabolism, protein biosynthesis and the regulation of gene activity. Due to its crucial function in defense enzymes (copper-zinc superoxide dismutase), zinc deficiency reduces resistance. In dairy animals zinc deficiency signs can be seen as bad hoof and horn quality, reduced fertility and poor udder health. Zinc is considered to be vital for proper sexual maturity, reproductive efficiency, regulation and onset of estrus (Green et al., 1998). GnRH secretion in the body is regulated by plasma zinc levels which is essential for secretion and maintaining the activity of FSH and LH (Das et al., 2009).

During periods of zinc deficiency due to alterations in synthesis and secretion of these hormones leads to arrest of ovulation, erratic estrus cycles and abnormal reproductive performance of animal (Kaswan and Bedwal 1995). Zinc takes part in maintenance of epithelial integrity of uterine lining in cattle for implantation of embryos and its insufficient levels is found to be associated with abortion, fetal mummification, lower birth weights and prolonged labor (Kumar et al., 2011). Stanton et al., (2000) reported that cows receiving organic trace minerals exhibited higher pregnancy rates to AI than those receiving inorganic trace minerals. Bisla et al., (2006) and Kumar (2008) recorded more number of animals exhibited estrus and improved in the conception rate in postpartum anoestrus buffaloes with mineral supplementation. Jyoti Sharma et al., (2009) observed estrus in 66.67 per cent of the cattle fed with concentrate feed containing dicalcium phosphate, copper sulphate and magnesium sulphate. Transition period is an important and vulnerable period encountered by dairy cow that extends from three weeks before and after calving (Curtis et al., 1985, 
Grummer 1995). Dairy cow experience about one-third decrease in feed intake during the last three weeks prior to calving, with significant reduction observed in the final week before parturition (Hayirli et al., 2002). This is mainly due to increase in concentration of circulating estrogen and less capacity for rumen to expand because of increased foetus size. After calving, the cow which was already consuming low proportion of dietary energy, mobilizes fat (NEFA) from adipose tissues as a source of energy for maintenance of body functions and to support milk production resulting into negative energy balance (Moore et al., 2005). Circulating concentration of blood metabolites like NEFA and BHBA have negative effect on post-partum fertility leading to anoestrous, low conception rates, long calving interval with decreased survivability of embryo in subsequent pregnancies (Staples et al., 1990).

\section{Materials and Methods}

\section{Location}

All procedures were approved by the Institutional Animal Ethics Committee (IAEC: GADVASU/2018/IAEC/45/01). Study was conducted on 14 primiparous buffaloes being reared at Directorate Livestock Farm, Guru Angad Dev Veterinary and Animal Sciences University, Punjab, India $\left(30.9^{\circ} \mathrm{N}, 75.85^{\circ} \mathrm{E}\right.$ and $256 \mathrm{~m}$ above sea level), where the climate is humid sub-tropical with defined seasons.

\section{Selection of Animals}

All the buffaloes selected were in first parity having a body condition score of $\geq 3$. Buffaloes were selected 60 days before calving and maintained until artificial insemination. All these buffaloes were maintained under general managemental practices as followed for pregnant animals in the herd at the Directorate Livestock Farm,
GADVASU, Ludhiana. The feed and water were available ad lib to these animals. At the beginning of the experiment the average age and body weight of buffaloes in control group was783.75 \pm 40.51 days and548.33 $\pm 32.91 \mathrm{~kg}$ and in treatment group was $716.67 \pm 42.82$ days and $562.0 \pm 38.65 \mathrm{~kg}$. Animals were housed in semi conventional housing system during the months of January 2018 to May 2019. Animals were divided into two groups control $(n=7)$ and treatment $(n=7)$.

\section{Feeding}

The nutrient requirements of the animals were mostly met with ad lib green fodder and measured amount of concentrate. The green fodders grown in the institute farm, were supplied according to the seasonal availability. The concentrate was fed at the rate of 2.5 $\mathrm{kg}$ /day per animal for body maintenance to heifers. For pregnant animals $1 \mathrm{~kg} /$ day/animal (upto seven months) and $2 \mathrm{~kg} /$ day/animal during advanced pregnancy (last 90 days). Milking buffaloes were given additional concentrate at the rate of $1.0 \mathrm{~kg}$ for every 1.5 $\mathrm{kg}$ milk production, above $5.0 \mathrm{~kg}$ milk yield. The concentrate to the milking animals was fed in divided allowances during milking. The diets provided for pre and post-calving cows, as well as the chemical analyses are shown in Table 1 and 2. Control group $(n=7)$ was fed as per the standards followed at Dairy Farm, Guru Angad Dev Veterinary and Animal Sciences University, Ludhiana. Treatment group $(n=7)$ was supplemented with organic copper and zinc supplementation in addition to normal feeding, Copper@225mg, Zinc@1.0gm per animal per day, 60 days before the expected date of calving till the date of artificial insemination.

\section{Blood Sampling}

All buffaloes were subjected to blood sampling $(10 \mathrm{ml})$, through jugular vein- 
puncture at weekly interval after parturition until artificial insemination in both group I and II. Blood samples were collected into spinwin conical tubes (Tarsons Products Pvt. Ltd. Maharashtra, India) which were immediately placed in the icebox and transferred to the laboratory. Serum was harvested by centrifugation $(3000 \mathrm{rpm}, 15$ minutes) and stored at $-20^{\circ} \mathrm{C}$ until the hormonal and metabolic profiling.

\section{Hormonal and metabolic profiling}

Serum progesterone and estradiol estimation was done using a solid phase enzyme immunoassay kits. ELISA kits used for $\mathrm{P}_{4}$ and $\mathrm{E}_{2}$ were manufactured by XEMA Co. Ltd (Moscow, Russia) with catalog number K207 and K208 respectively. The sensitivity of the progesterone and estradiol assay was 0.6 $\mathrm{ng} / \mathrm{ml}$ and $62.4 \mathrm{pg} / \mathrm{ml}$.

For estimation of serum NEFA sandwich ELISA KIT manufactured by Bioassay Technology Laboratory (Shanghai, China) with catalog number E0021Bo was used. Total protein estimation was done using the VITROS chemistry products TP Slides (Ortho Clinical Diagnostics, Mumbai, India) and the VITROS Chemistry Products DT Calibrator Kit on VITROS DT 60/DT60 2 Chemistry Systems (Ortho- Clinical Diagnostics, Johnson and Johnson, SA).

\section{Statistical analyses}

Data generated by ultrasound examination and hormone assay were subjected to statistical analysis using IBM SPSS Statistical Version 23 (SPSS 23.0 for windows; SPSS, Chicago, IL, USA). To compare the effect of treatment on serum $\mathrm{P}_{4}$ concentration $(\mathrm{ng} / \mathrm{ml})$, serum $\mathrm{E}_{2}$ concentration $(\mathrm{pg} / \mathrm{ml})$, TP value $(\mathrm{g} / \mathrm{dl})$ and NEFA concentration $(\mu \mathrm{mol} / \mathrm{l})$ over days within the group, data were analyzed using "One way ANOVA". The whole of the analyzed data is presented as Mean \pm SEM. A probability level of $(p<0.05)$ was considered significant.

\section{Results and Discussion}

\section{Blood metabolic profile in postpartum primiparous buffaloes fed trace mineral supplement}

Mean serum NEFA values obtained across different days in treatment and control group are presented in Table 3. Concentration of NEFA were highest at the day of calving $(388.88 \pm 3.73$ and $405.27 \pm 2.63 \mu \mathrm{mol} / \mathrm{l})$ and lowest on day 56 postpartum $(334.40 \pm 2.86$ and $352.92 \pm 5.45 \mu \mathrm{mol} / \mathrm{l}$ ) in treatment and control groups respectively. A significant $(\mathrm{p}<0.05)$ decrease in the serum NEFA levels $(\mu \mathrm{mol} / \mathrm{l})$ was observed in supplemented than control group buffaloes.

Concentration of NEFA peaked on the day of calving and then decreased on day 7 postpartum in both the groups but decrease was more rapid in treatment group as compared to control group (Figure 1), and is in affirmation of studies by Vazquez-Anon $\mathrm{M}$ et al., (1994) and Grum DE et al., (1996). Accorsi et al., reported higher NEFA levels until first 10 days after calving. Yang WZ et al., (1996) reported that control buffaloes had higher NEFA concentrations when compared to buffalo receiving chromium, suggesting greater mobilization of body reserves. Nonesterified fatty acids and BHBA are considered as markers of negative energy balance during the transition period (Ospina $e t$ al., 2010 a,b, Chapinal et al., 2011, McArt et al., 2012 b). Elevation of NEFA or BHBA concentrations during pre- and postpartum periods have been associated with negative downstream outcomes in individual animals, such as decreased milk production (Duffield $e t$ al., 2009, Ospina et al., 2010b, McArt et al., 2012b), decreased reproductive function (Ospina et al., 2010b, McArt et al., 2012b, 
Garverick et al., 2013), increased risk of health disorders (LeBlanc et al., 2005, McArt et al., 2012a), and increased risk of removal from the herd (Ospina et al., 2010a, Roberts et al., 2012, McArt et al., 2012b), as well as on a herd level basis (Ospina et al., 2010c). Findings are suggestive of better feed utilization and assimilation of available energy in supplemented group, treated animals maintained better energy balance and reproductive performance than the control animals. Serum total protein levels across different days in treatment and control groups are presented in Table 3.

Fig.1 Serum NEFA $(\mu \mathrm{mol} / \mathrm{l})$ and total protein $(\mathrm{g} / \mathrm{dl})$ comparison between treatment and control groups

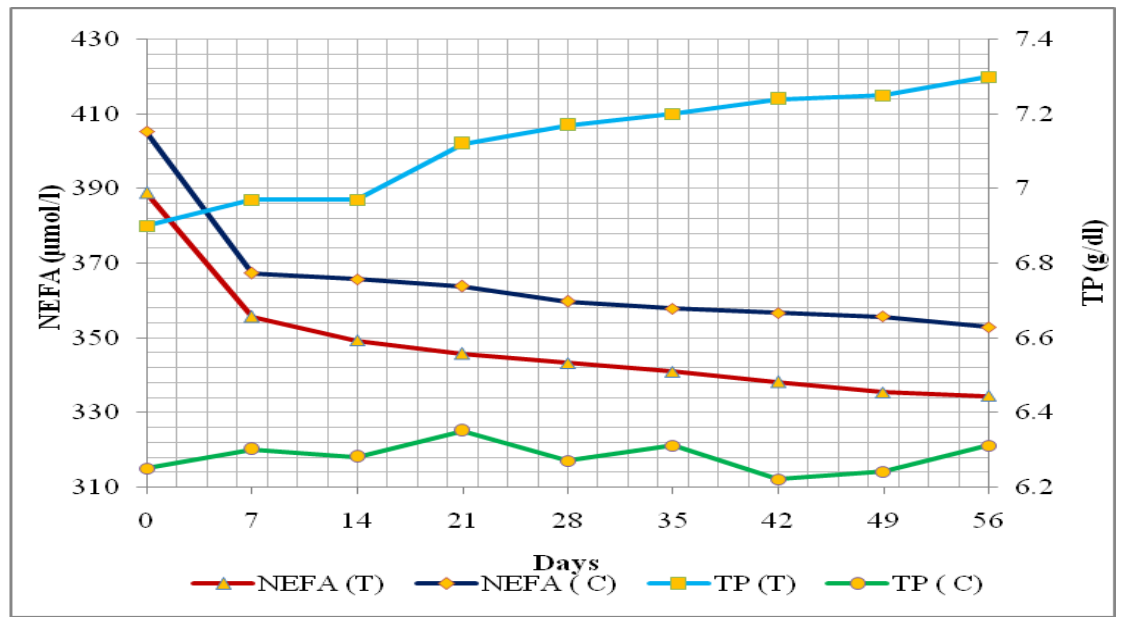

NEFA (T): NEFA in treatment group; NEFA (C): NEFA in control group; TP (T): Total protein in control group; TP (C) Total protein in treatment group

Fig.2 Serum progesterone $(\mathrm{ng} / \mathrm{ml})$ and estradiol $(\mathrm{pg} / \mathrm{ml})$ comparison between treatment and control groups

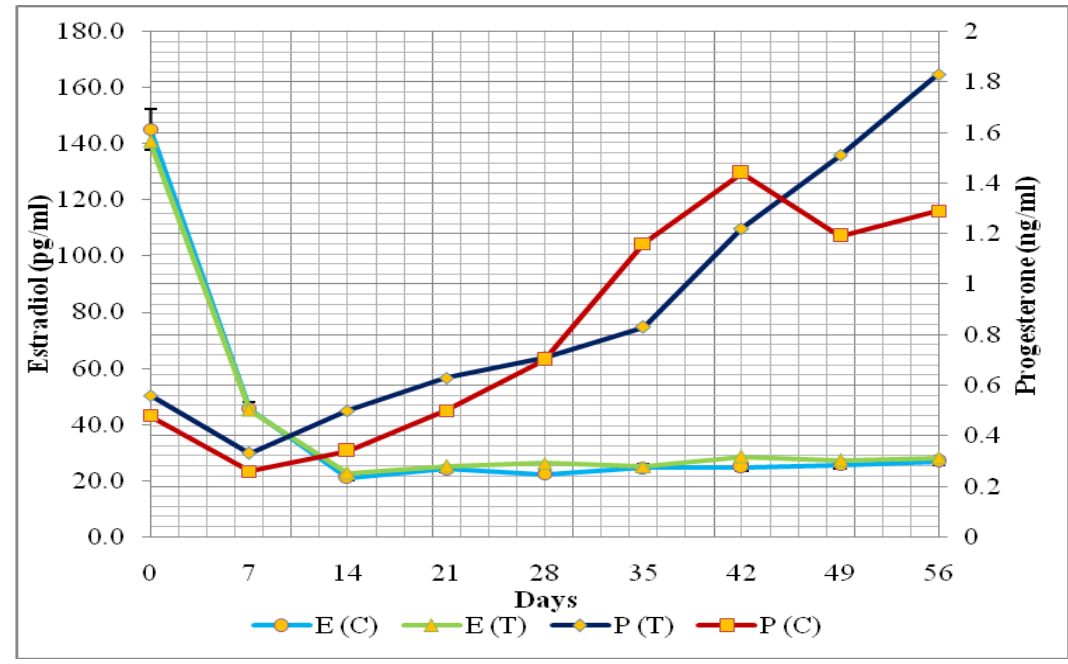

E(C): Estradiol in control group; E (T): Estradiol in treatment group; P (T): Progesterone in control group; P (C) Progesterone in treatment group 
Table.1 Ingredient composition of concentrate mixtures (\%)

\begin{tabular}{|c|c|c|c|c|c|c|c|c|c|c|c|c|c|}
\hline Ingredient & Maize & $\begin{array}{c}\text { Soybean } \\
\text { meal }\end{array}$ & $\begin{array}{c}\text { Mustard } \\
\text { cake }\end{array}$ & $\begin{array}{c}\text { Full } \\
\text { fat } \\
\text { soya }\end{array}$ & $\begin{array}{c}\text { Guar } \\
\text { Korma }\end{array}$ & $\begin{array}{c}\text { Cotton } \\
\text { seed } \\
\text { meal }\end{array}$ & $\begin{array}{c}\text { Deoiled } \\
\text { Rice } \\
\text { bran }\end{array}$ & $\begin{array}{c}\text { Mineral } \\
\text { mixture }\end{array}$ & $\begin{array}{c}\text { Calcite } \\
\text { powder }\end{array}$ & $\begin{array}{c}\text { Salt } \\
\text { Yeasac }\end{array}$ & $\begin{array}{c}\text { Toxin } \\
\text { binder }\end{array}$ & $\begin{array}{c}\text { Vitamin } \\
\text { mix }\end{array}$ \\
\hline $\begin{array}{c}\text { Concentrat } \\
\text { e Mixture } \\
(\boldsymbol{\%})\end{array}$ & 40.00 & 10.00 & 20.00 & 2.00 & 3.00 & 4.00 & 16.7 & 2.00 & 0.50 & 1.50 & 0.10 \\
\hline
\end{tabular}

Table.2 Composition of Mineral mixtures (\%)

\begin{tabular}{|c|c|c|c|l|l|c|c|c|c|c|}
\hline $\begin{array}{c}\text { Type of } \\
\text { mineral } \\
\text { Source }\end{array}$ & $\begin{array}{c}\text { Di } \\
\text { Calcium } \\
\text { Phosphate }\end{array}$ & $\begin{array}{c}\text { Limestone } \\
\text { Powder }\end{array}$ & $\begin{array}{c}\text { Magnesium } \\
\text { Oxide }\end{array}$ & $\begin{array}{c}\text { Magnesium } \\
\text { Sulphate }\end{array}$ & $\begin{array}{c}\text { Copper } \\
\text { Sulphate }\end{array}$ & $\begin{array}{c}\text { Iron } \\
\text { Sulphate }\end{array}$ & $\begin{array}{c}\text { Manganese } \\
\text { Sulphate }\end{array}$ & $\begin{array}{c}\text { Potassium } \\
\text { Iodate }\end{array}$ & $\begin{array}{c}\text { Cobalt } \\
\text { Sulphate }\end{array}$ & $\begin{array}{c}\text { Zinc } \\
\text { Sulphate }\end{array}$ \\
\hline $\begin{array}{c}\text { Mineral } \\
\text { Mixture } \\
(\%)\end{array}$ & 59.77 & 21.98 & 07.83 & 04.98 & 0.427 & 01.50 & 0.427 & 0.050 & 0.050 & 02.99 \\
\hline
\end{tabular}


Table.3 Blood NEFA and TP levels (Mean \pm SEM) in postpartum primiparous buffaloes fed trace mineral supplement

\begin{tabular}{|c|c|c|c|c|}
\hline \multirow{2}{*}{ Days } & \multicolumn{2}{|c|}{$* \mathbf{N E F A}(\boldsymbol{\mu m o l} / \mathbf{l})$} & \multicolumn{2}{c|}{$* \mathbf{T P}(\mathbf{g} / \mathbf{d l})$} \\
\cline { 2 - 5 } & Treatment $(\mathbf{n}=7)$ & Control $(\mathbf{n}=7)$ & Treatment $(\mathbf{n}=7)$ & Control $(\mathbf{n}=7)$ \\
\hline $\mathbf{0}$ & $388.88 \pm 3.73$ & $405.27 \pm 2.63$ & $6.90 \pm 0.06$ & $6.25 \pm 0.23$ \\
\hline $\mathbf{7}$ & $355.61 \pm 3.97$ & $367.34 \pm 2.29$ & $6.97 \pm 0.04$ & $6.30 \pm 0.21$ \\
\hline $\mathbf{1 4}$ & $349.27 \pm 4.11$ & $365.63 \pm 3.14$ & $6.97 \pm 0.05$ & $6.28 \pm 0.15$ \\
\hline $\mathbf{2 1}$ & $345.65 \pm 4.35$ & $363.82 \pm 2.60$ & $7.12 \pm 0.05$ & $6.35 \pm 0.22$ \\
\hline $\mathbf{2 8}$ & $343.24 \pm 4.30$ & $359.70 \pm 3.88$ & $7.17 \pm 0.05$ & $6.27 \pm 0.20$ \\
\hline $\mathbf{3 5}$ & $340.93 \pm 4.38$ & $357.86 \pm 4.89$ & $7.20 \pm 0.11$ & $6.31 \pm 0.17$ \\
\hline $\mathbf{4 2}$ & $338.07 \pm 3.56$ & $356.59 \pm 4.85$ & $7.24 \pm 0.11$ & $6.22 \pm 0.20$ \\
\hline $\mathbf{4 9}$ & $335.35 \pm 3.49$ & $355.70 \pm 6.13$ & $7.25 \pm 0.07$ & $6.24 \pm 0.14$ \\
\hline $\mathbf{5 6}$ & $334.40 \pm 2.86$ & $352.92 \pm 5.45$ & $7.35 \pm 0.05$ & $6.31 \pm 0.16$ \\
\hline
\end{tabular}

*Significant difference at $\mathrm{p}<0.05$ level

Table.4 Blood progesterone and estradiol levels (Mean \pm SEM) in postpartum primiparous buffaloes fed trace mineral supplement

\begin{tabular}{|c|c|c|c|c|}
\hline \multirow{2}{*}{ Days } & \multicolumn{2}{|c|}{ Progesterone (ng/ml) } & \multicolumn{2}{c|}{ Estradiol (pg/ml) } \\
\cline { 2 - 5 } & Treatment $(\mathbf{n}=\mathbf{7})$ & Control $(\mathbf{n}=\mathbf{7})$ & Treatment $(\mathbf{n}=7)$ & Control $(\mathbf{n}=7)$ \\
\hline $\mathbf{0}$ & $0.56 \pm 0.009$ & $0.48 \pm 0.02$ & $140.82 \pm 0.51$ & $145.23 \pm 0.39$ \\
\hline $\mathbf{7}$ & $0.33 \pm 0.01$ & $0.26 \pm 0.01$ & $45.17 \pm 0.30$ & $45.70 \pm 0.17$ \\
\hline $\mathbf{1 4}$ & $0.50 \pm 0.07$ & $0.34 \pm 0.01$ & $22.67 \pm 0.42$ & $21.04 \pm 0.16$ \\
\hline $\mathbf{2 1}$ & $0.63 \pm 0.01$ & $0.50 \pm 0.006$ & $25.25 \pm 0.27$ & $24.10 \pm 0.40$ \\
\hline $\mathbf{2 8}$ & $0.71 \pm 0.009$ & $0.70 \pm 0.01$ & $26.32 \pm 0.42$ & $22.39 \pm 0.46$ \\
\hline $\mathbf{3 5}$ & $0.83 \pm 0.02$ & $1.16 \pm 0.07$ & $24.98 \pm 0.28$ & $24.55 \pm 0.27$ \\
\hline $\mathbf{4 2}$ & $1.22 \pm 0.08$ & $1.44 \pm 0.04$ & $28.52 \pm 0.33$ & $24.77 \pm 0.19$ \\
\hline $\mathbf{4 9}$ & $1.51 \pm 0.04$ & $1.19 \pm 0.02$ & $27.33 \pm 0.33$ & $25.66 \pm 0.27$ \\
\hline $\mathbf{5 6}$ & $1.83 \pm 0.06$ & $1.29 \pm 0.08$ & $28.16 \pm 0.34$ & $26.86 \pm 0.47$ \\
\hline
\end{tabular}

Total protein in treatment group was highest $(7.35 \pm 0.05 \mathrm{~g} / \mathrm{dl})$ and lowest $(6.90 \pm 0.06 \mathrm{~g} / \mathrm{dl})$ on day 56 and 0 postpartum, respectively. While in control group the concentration was highest $(6.35 \pm 0.22 \mathrm{~g} / \mathrm{dl})$ and lowest $(6.22 \pm 0.20 \mathrm{~g} / \mathrm{dl})$ on day 21 and 42 postpartum, respectively.

Total protein increased after parturition in treatment group, while in control group the concentration of total protein did not change significantly after parturition. There was significant difference $(p<0.05)$ in total protein values between treatment and control group (Figure 1).

Results obtained were in affirmation with Nagalakshmi et al., (2016), wherein, increased concentration of total protein was observed in animals supplemented with organic $\mathrm{Zn}$ compared to inorganic $\mathrm{Zn}$. Shakweer et al., (2010) also observed increase in total protein concentration due to zinc supplementation. Mousa and EL-Sheikh (2004) revealed that addition of 80 and 120 mg zinc sulfate improved total protein in 
blood serum of lactating buffaloes. Similar findings, by Shakweer et al., (2005), Shakweer and EL-Nahas (2005) and Shakweer et al., (2006) found increased concentration of total protein with different level of zinc methionine supplementation.

As the calving approaches, negative energy balance and catabolism of body tissue increases which leads to degradation of the body fat and the body protein. DMI decrease is a prelude to decreased protein availability in the body leading to blood protein level reduction as ammonia is not available for the synthesis of amino acid. Strang et al., (1998) reported that triglyceride loaded hepatocytes were less sensitive to the hormonal stimulation for albumin and protein synthesis than normal hepatocytes. Increased level of NEFA in the control group may be the reason of decreased level of total protein in the control group.

\section{Hormonal levels in postpartum primiparous buffaloes fed trace mineral supplement}

Serum progesterone values obtained across different days in the treatment and control groups are presented in Table 4. Higher progesterone concentration was $1.83 \pm 0.06$ $\mathrm{ng} / \mathrm{ml}$ on day 56 and $0.33 \pm 0.01 \mathrm{ng} / \mathrm{ml}$ on day 7 postpartum in the treatment group. In control group animals higher concentration was $1.44 \pm 0.04$ and $0.26 \pm 0.01 \mathrm{ng} / \mathrm{ml}$ on day 42 and 7 postpartum, respectively. Progesterone concentrations were at baseline level within 24 hours from calving with a rising trend from day 7 postpartum in both treatment and control groups. Trace mineral supplemented buffaloes had slightly higher levels on all days except on day 35 and 42 postpartum wherein the control group had slightly higher values of progesterone (Figure 2 ). Serum progesterone values in this study corroborated well with the earlier reports in buffaloes (Prakash and Madan 1986). Similar results were observed by Singh et al., (2012). Dhami et al., (2015) reported similar results in cattle. Kalasariya et al., (2017) observed that mineral supplementation had no significant effect on progesterone concentration and was true for present work.

Mean serum estradiol values obtained across different days of the study in treatment and control groups are presented in Table 4. Estradiol was highest $140.82 \pm 0.51 \mathrm{pg} / \mathrm{ml}$ on day of calving and lowest $22.67 \pm 0.42 \mathrm{pg} / \mathrm{ml}$ on day 14 postpartum in treatment group while in control group the concentration was highest $145.23 \pm 0.39 \mathrm{pg} / \mathrm{ml}$ and lowest $21.04 \pm 0.16 \mathrm{pg} / \mathrm{ml}$ on day 0 and 14 postpartum, respectively. Estradiol values peaked on the day of parturition and showed a decreasing trend thereafter in both treatment and control group as depicted in Figure 4. Estradiol showed a rising trend from day 7 postpartum in both the groups.

Trace mineral supplemented group had slightly higher concentration of Estradiol on all days except on day 0 and 7 postpartum wherein control group had slightly higher values of Estradiol (Figure 2). Values obtained were similar to the findings of Kalasariya et al., (2017) and also agreed to the trend of postpartum Estradiol profile reported by Singh et al., (2012). Arya and Madan (2001) reported similar Estradiol values postpartum. Dhami et al., (2015) observed similar results in cattle.

Supplementation of copper at the rate of $225 \mathrm{mg}$ and zinc at the rate of $1.0 \mathrm{gm}$ per animal per day significantly improves the total protein and non-esterified fatty acid levels in blood thus helps in proper mobilisation and utilisation of body reserves. However it did not affect the blood hormonal profile significantly but still there exist some numerical difference among their values from control group. Hence, chelated mineral 
supplementation during pre and post-partum period is better option to improve the reproductive performance in primiparous buffaloes.

\section{References}

Accorsi PA, Camberoni A, Isani G, Viggiani R, Monari M, De Ambrogi M, Munno A, Tamanini C, Seren E. 2005. Leptin does not seem to influence glucose uptake by bovine mammary explants. $J$ Physiol Pharmacol 56: 689-698

Arya J S and Madan M L. 2001. Post-partum reproductive cyclicity based on ovarian steroids in suckled and weaned buffaloes. Buffalo Journal. 17(3): 361370.

Bisla RS, Singh U, Chaudhri SS and Dahiya AS. 2006. Effect of dietary supplementation with mineral mixture and anti helmintic treatment on production and fertility response in rural anestrus buffaloes. Haryana Veterinarian 45: 82-84.

Chapinal N, Carson M E, Duffield T F, Capel M, Godden S, Overton M W, Santos J E $\mathrm{P}$ and LeBlanc S J. 2011. The association of serum metabolites with clinical disease during the transition period. J. Dairy Sci. 94: 4897-4903.

Curtis CR, Erb HN, Sniffen CJ, Smith RD and Kronfeld DS. 1985. Path analysis of dry period nutrition, postpartum metabolic and reproductive disorders, and mastitis in Holstein cows. Journal of Dairy Science 68: 2347-2360.

Das J M, Dutta P, Deka K C, Biswas R K, Sarmah B C and Dhali A. 2009. Comparative study on serum macro and micro mineral profiles during oestrus in repeat breeding crossbred cattle with impaired and normal ovulation. Livestock Research for rural development. 21: 5

Dhaliwal GS. 2005. Managing dairy herds for optimal reproductive efficiency. Recent concepts in physio-pathology of animal reproduction, 1-9. In Centre of Advanced studies in Veterinary Gynaecology and Reproduction. Punjab Agricultural University, Ludhiana, India.

Dhami A J, Theodore V K, Panchal M T, Hadiya $\mathrm{K}$ K, Lunagariya $\mathrm{P} M$ and Sarvaiya NP. 2017. Effect of peripartum nutritional supplementation on postpartum fertility and blood biochemical and steroid hormone profile in crossbred cows. Indian Journal of Animal Research, 51(5).

Duffield T F, Lissemore K D, McBride B W and Leslie $\mathrm{K}$ E. 2009. Impact of hyperketonemia in early lactation dairy cows on health and production. J. Dairy Sci. 92: 571-580.

Garg M R, Bhanderi B M and Sherasia P L. 2009. Macro and micro-mineral status of feeds and fodders fed to buffaloes in semi-arid zone of Rajasthan. Animal Nutrition and Feed Technology. 9(2): 209-220

Garverick H A, Harris M N, Vogel-Bluel R, Sampson J D, Bader J, Lamberson W R, Spain J N, Lucy M C and Youngquist R S. 2013. Concentrations of nonesterified fatty acids and glucose in blood of periparturient dairy cows are indicative of pregnancy success at first insemination. $J$. Dairy Sci. 96: 181-188.

Green 1 W, Johnson A B, Paterson J and Ansotegui R. 1998. Feedstuffs. 70: 58

Grum D E, Drackley J K, Younker R S, La Count D W and Veenhuizen JJ. 1996 Nutrition during the dry period and hepatic lipid metabolism of periparturient dairy cows. J Dairy Sci 79: 1850-1864

Grummer RR. 1995. Impact of changes in organic nutrient metabolism on feeding the transition dairy cow. Journal of Animal Science 73: 2820-2833.

Hayirli A, Grummer RR, Nordheim E V, and Crump P M. 2002. Animal and dietary factors affecting feed intake during the prefresh transition period in Holsteins. Journal of Dairy Science 85: 3430-3443.

Jyoti Sharma, Anil Kumar, Tiwari D P, Mondal B C. 2009. Effect of dietary supplementation of calcium, copper and 
manganese on production performance of dairy cattle in Pithoragarh district of Uttarakhand. Indian Journal of Animal Sciences. 79: 686-691

Kalasariya R M, Dhami A J, Hadiya K K, Borkhatariya D N and Patel J A. 2017. Effect of peripartum nutritional management on plasma profile of steroid hormones, metabolites, and postpartum fertility in buffaloes. Veterinary world. 10(3): 302.

Kaswan S and Bedwal R S. 1995. Light and electron. Microscopic changes in the ovary of zinc deficient BALB/c mice. Indian J. Exp. Biol. 33: 469

Kumar RK. 2008. Reproductive performance of dairy buffaloes by supplementing fortified mineral mixture in daily ration. Asian Journal of Animal Science. 3: 8-9.

Kumar S, Pandey A K, Razzaque W A A and Dwivedi D K. 2011. Importance of micro minerals in reproductive performance of livestock. Vet. World. 4(5): 230-233

Leblance S J, Leslie K E and Duffieid T D. 2005. Metabolic predictors of displaced abomasum in dairy cattle. J. Dairy Sci. 88: $159-170$.

McArt J A A, Nydam D V and Oetzel G R. 2012a. A field trial on the effect of propylene glycol on displaced abomasum, removal from herd, and reproduction in fresh cows diagnosed with subclinical ketosis. J. Dairy Sci. 95: 2505-2512.

McArt J A A, Nydam D V and Oetzel G R. 2012b. Epidemiology of subclinical ketosis in early lactation dairy cattle. $J$. Dairy Sci. 95: 5056-5066.

Michaluk A and Kochman K. 2007. Involvement of copper in female reproduction. J.Repro. Biol. 7(3): 193-205

Moore CE, Kay JK, VanBaale MJ, and Baumgard LH. 2005. Calculating and improving energy balance during times of nutrient limitations. Proc. Southwest Nutr. Conf. 173-185.

Mousa Kh M M and S M E L-Sheikh. 2004. Effect of different levels of zinc supplementation on utilization of nonprotein nitrogen for lactating buffaloes. $J$.
Agric. Sci. Mansoura Univ., 29(6): 30633073.

Nagalakshmi D, Rao K S, Kumari G A, Sridhar K and Satyanarayana M. 2016. Comparative evaluation of organic zinc supplementation as proteinate with inorganic zinc in buffalo heifers on health and immunity. Indian J. Anim. Sci. 86(3): 322-328.

Ospina P A, Nydam D V, Stokol T and Overton T R. 2010a. Evaluation of nonesterified fatty acids and beta-hydroxybutyrate in transition dairy cattle in the northeastern United States: Critical thresholds for prediction of clinical diseases. J. Dairy Sci. 93: 546-554.

Ospina P A, Nydam D V, Stokol T and Overton T R. 2010b. Associations of elevated nonesterified fatty acids and betahydroxybutyrate concentrations with early lactation reproductive performance and milk production in transition dairy cattle in the northeastern United States. $J$. Dairy Sci. 93: 1596-1603.

Ospina P A, Nydam D V, Stokol T and Overton T R. 2010c. Association between the proportion of sampled transition cows with increased nonesterified fatty acids and beta-hydroxybutyrate and disease incidence, pregnancy rate, and milk production at the herd level. J. Dairy Sci. 93: 3595-3601.

Phillippo M, Humphries W R and Atkinson T. 1987. The effect of dietary molybdenum and iron on copper status, puberty, fertility and oestrous cycles in cattle. $J$. Agric. Sci. 109: 321-326

Prakash B S and Madan M L. 1986. Peripheral plasma oestradiol-17 $\beta$, progesterone and cortisol in buffaloes induced to calve with dexamethasone and vetoestrol. Animal Reproduction Science. 11: 111-122.

Roberts T, Chapinal N, LeBlanc S J, Kelton D F, Dubuc J and Duffield T F. 2012. Metabolic parameters in transition cows as indicators for early-lactation culling risk. J. Dairy Sci. 95: 3057- 3063.

Shakweer I M E and EL-Nahas H M. 2005. Productive performance of suckling 
calves fed diets supplemented with zinc methionine. J. Agric. Sci. Mansoura Univ. 30(6): 3037-3046.

Shakweer I M E, EL-Mekass A A M and ELNahas H M. 2005. Effect of different levels of supplemented organic zinc source on performance of Friesian dairy cows. J. Agric. Sci. Mansoura Univ. 30(6): 3025-3035

Shakweer I M E, EL-Mekass A A M and ELNahas H M. 2006. Effect of supplemental zinc methionine concentrations on digestibility, feed efficiency and some ruminal and blood parameters and performance of Friesian calves. J. Agric. Sci. Mansoura Univ. 31(8): 4935-4935.

Shakweer I M E, El-Mekass A A M and ElNahas H M. 2010. Effect of two different sources of zinc supplementation on productive performance of Friesian dairy cows. Egyptian J. Anim. Prod. 47(1), pp. 11-22.

Singh AP, Shah RS, Singh RB, Akhtar MH, Roy GP, Singh C and V Kunj. 2006. Response of mineral mixture, Prajana and GnRH on serum biochemical constituents and conception rate in anoestrus buffaloes. Indian Journal of Animal Reproduction 27(1): 51-54.

Singh S P, Mehla R K and Singh M. 2012. Plasma hormones, metabolites, milk production, and cholesterol levels in
Murrah buffaloes fed with Asparagus racemosus in transition and postpartum period. Tropical animal health and production. 44(8): 1827-1832.

Stanton TL, Whittier JC, Geary TW, Kimberling CV and Johnson AB. 2000. Effects of trace mineral supplementation on cow-calf performance, reproduction, and immune function. Prof. Animal Science 16: 121-127.

Staples CR, Thatcher WW, and Clark JH. 1990. Relationship between ovarian activity and energy status during the early postpartum period of high producing dairy cows. Journal of Dairy Science 73: 938-947

Strang B D, Bertics S J, Grummer R R and Armentano L E. 1998. Relationship of triglycerides accumulation to insulin clearance and hormonal responsiveness in bovine hepatocytes. J. Dairy Sci. 81: 740747

Vazquez-Anon $M$, Bertics S, Luck $M$, Grummer R, Pinheiro J. 1994. Peripartum liver triglyceride and plasma metabolites in dairy cows. J Dairy Sci 77: 1521-1528

Yang WZ, Mowat DN, Subiyatno A, Liptrap RM. 1996. Effects of chromium supplementation on early lactation performance of Holstein cows. Can $J$ Anim Sci 76: 221-230

\section{How to cite this article:}

Arashdeep Kaur, Prahlad Singh, Mrigank Honparkhe, R. S. Grewal, Ajeet Kumar, Ashwani Kumar Singh, Navdeep Singh, Shahbaz Singh Dhindsa and Ankit Kumar Ahuja. 2019. Effect of Peripartum Organic Zinc and Copper Supplementation on Blood Metabolic and Hormonal Profiling of Primiparous Buffaloes. Int.J.Curr.Microbiol.App.Sci. 8(09): 2858-2868. doi: https://doi.org/10.20546/ijcmas.2019.809.328 